\title{
EDITORIAL
}

\section{Considerações sobre a produção e a divulgação do conhecimento histórico em tempos de negacionismo}

\section{Considerations about the Production and Dissemination of Historical Knowledge in Times of Negationism}

No editorial da edição da Revista Brasileira de História publicada no segundo semestre de 2019, que inaugurou os trabalhos da atual gestão à frente da revista, o novo editor, Valdei Araújo, chamou nossa atenção para as práticas de desinformação, má-fé, descaso e mentiras, adotadas pelo atual governo federal em relação ao episódio de vazamento de combustível no mar, no Nordeste do Brasil, e para as ameaças ao meio ambiente e às populações tradicionais da Amazônia. Naquela edição, os artigos do dossiê sobre a Amazônia demonstraram, entre outras questões, a pertinência da pesquisa histórica e da divulgação de seus resultados como uma das formas de se contrapor às referidas narrativas.

Infelizmente, no início do ano seguinte, fomos assolados, em escala global, por uma nova doença, a pandemia causada pela COVID-19. Não havia vacinas e nem medicamentos que promovessem a cura. Em que pese as insistentes recomendações de autoridades sanitárias, em especial de infectologistas, da adoção do isolamento social, bem como do uso do álcool em gel e da máscara, como as medidas mais eficazes para a redução da possiblidade de contágio, verificaram-se, em diversas ocasiões, manifestações do presidente da República e de muitos de seus apoiadores contrárias ao isolamento social, minimizando o perigo representado pela doença e indicando o uso de medicamentos do denominado "tratamento precoce", cuja eficácia no combate ao vírus não é comprovada cientificamente.

O negacionismo promovido por pessoas que ocupam lugares de poder em nosso país não tem como alvo somente as Ciências da Saúde ou os pesqui- 
sadores que frequentemente nos alertam acerca da crise ambiental que nos ameaça, mas também as Ciências Humanas. Diversos acontecimentos históricos ocorridos no Brasil e em outros países foram objetos de manifestações que distorciam, falseavam e/ou contrariavam fatos e resultados de pesquisas de historiadores e de cientistas sociais.

Como afirma Luís Edmundo de Souza Moraes (2011), o termo "negacionismo" passou a ser utilizado no lugar da palavra "revisionismo". De maneira geral, o negacionismo é um fenômeno político-intelectual ligado a movimentos de extrema-direita na Europa e nos EUA, que aflorou após a Segunda Guerra Mundial. Inicialmente, o foco das teses negacionistas - ou revisionistas - era negar que o Holocausto havia acontecido (Jesus; Gandra, 2020). Com o passar do tempo, o escopo dos negacionistas se ampliou, como, por exemplo, no caso de indústrias petrolíferas e de geração de energia em termoelétricas, que negam ou questionam a sua responsabilidade na emissão de gases causadores do efeito estufa (Leite, 2014). No Brasil, atualmente, muitas narrativas negacionistas objetivam deslegitimar algumas lutas e conquistas de grupos que historicamente foram explorados e/ou marginalizados em nossa sociedade, como negros, quilombolas, indígenas e mulheres.

Por outro lado, é digno de destaque um importante êxito dos historiadores como categoria profissional: a promulgação da Lei 14.038, publicada em 18 de agosto de 2020, que regulamenta a profissão de historiador. Diante disso, é oportuno registrar aqui um fragmento que sintetiza essa conquista:

Pelo texto, poderá ser historiador quem tem diploma de curso superior, mestrado ou doutorado em história; diploma de mestrado ou doutorado obtido em programa de pós-graduação reconhecido pela Coordenação de Aperfeiçoamento de Pessoal de Nível Superior (Capes) com linha de pesquisa dedicada a história; e profissionais diplomados em outras áreas que comprovarem ter exercido a profissão por mais de cinco anos a contar do dia 17 de agosto, data de promulgação da lei. [...] $\S$ Entre as atribuições dos historiadores, o texto prevê o magistério da disciplina de história nas escolas de ensino fundamental e médio, desde que cumprida a exigência da Lei de Diretrizes e Bases da Educação Nacional (Lei 9.394, de 1996) quanto à obrigatoriedade da licenciatura. [...] $\$$ O profissional poderá ainda planejar, organizar, implantar e dirigir serviços de pesquisa histórica; assessorar, organizar, implantar e dirigir serviços de documentação e informação histórica; e elaborar pareceres, relatórios, planos, projetos, laudos e trabalhos sobre temas históricos (Da Redação, 2020). 
Fruto de uma longa luta da Associação Nacional de História ANPUH, essa vitória também deve ser encarada como uma importante arma para a valorização de nosso ofício, especialmente em função do atual contexto de menosprezo, ou até, em muitos casos, de desprezo às Ciências Humanas, por parte de pessoas que ocupam lugares de poder como, por exemplo, aqueles que estão no comando de órgãos de fomento. E isso pode ser evidenciado, de forma concreta, aos verificarmos a drástica redução de recursos destinados à pesquisa na área, ou, em seu aspecto extremo, o fim das bolsas de iniciação científica do CNPq para as Ciências Humanas.

Portanto, há quase um ano da regulamentação de nossa profissão, tudo indica que nossos esforços em prol do reconhecimento e da valorização de nosso ofício devem ser redobrados. Nunca é demais ressaltar: não se trata de não aceitar questionamentos em torno da escrita da história, mas de reafirmar o caráter fundamental da História como Ciência e Arte: uma operação de investigação cujos resultados devem estar constantemente submetidos ao crivo do debate, do contraditório, dos diversos mecanismos de averiguação e controle da disciplina; afinal, trata-se de um conhecimento produzido a partir de fontes e do diálogo historiográfico. Esses são os elementos inerentes ao trabalho dos historiadores e os aspectos que devemos sempre realçar para marcarmos nossa diferença e necessária oposição a todo tipo de negacionismo.

Nesse sentido, a RBH reafirma seu papel como instrumento de alto nível para a disseminação do conhecimento historiográfico e como espaço de debate e crítica dos resultados de diversos estudos produzidos em institutos de pesquisa e universidades brasileiras e estrangeiras. Por fim, também em nome dos demais membros do Conselho da $\mathrm{RBH}$, gostaria de aproveitar esse espaço para agradecer por essa valiosa oportunidade de contribuir para o fortalecimento de nossa revista, de nossa associação e de nosso ofício.

Toledo, PR, 5 de abril de 2021.

Marcos Nestor Stein

Universidade Estadual do Oeste do Paraná (UNIOESTE), Campus de Marechal Cândido Rondon, Colegiado do Curso de História e Programa de Pós-Graduação em História, PR Brasil.

Pesquisador do INCT Proprietas: História da Propriedade e Direitos de Acesso. steinmarcos886@gmail.com <https://orcid.org/0000-0002-2623-0686> 
Editorial

\section{REFERÊNCIAS}

JESUS, Carlos Gustavo Nóbrega de; GANDRA, Edgar Avila. O negacionismo renovado e o ofício do historiador. Estudos Ibero-Americanos, Porto Alegre, v. 46, n. 3, pp. $1-17,2020$.

LEITE, José Correa. Controvérsias científicas ou negação da ciência? A agnotologia e a ciência do clima. Scientice Studia, São Paulo, v. 12, n. 1, pp. 179-189, 2014.

MORAES, Luís Edmundo de Souza. O Negacionismo e o problema da legitimidade da escrita sobre o Passado. In: ANPUH, São Paulo, 2011. Anais do XXVI Simpósio Nacional de História - ANPUH, 2011, pp. 1-16.

DA REDAÇÃO. Publicada lei que regulamenta a profissão de historiador. 18 ago. 2020. Disponível em: https://www12.senado.leg.br/noticias/materias/2020/08/18/publicada-lei-que-regulamenta-a-profissao-de-historiador. Disponível em: 4 mar. 2021. 